\title{
THE EFFECT OF FRAUD DIAMOND ON FRAUDULENT FINANCIAL STATEMENT IN ASIA PACIFIC COMPANIES
}

\author{
Tanggor Sihombing ${ }^{1}$ \\ Universitas Pelita Harapan \\ tanggor.sihombing@uph.edu \\ Celine Celiana Cahyadi \\ Universitas Pelita Harapan \\ celineceliana@gmail.com
}

Diterima 11 Mei 2021

Disejutui 19 Juni 2021

\begin{abstract}
This study aims to determine how the influence of fraud diamonds in detecting fraudulent financial statements in companies in Asia-Pacific listed in S\&P in 2017-2019. The study used a purposive sampling method with a total population of 228 companies with a sample of 78 companies and used the STATA program for analysis. The results of the hypothesis testing carried out were that the pressure on financial stability had an effect on fraudulent financial statements with a significant level of 0.000 which was smaller than the significant level in this study which was 0.0101 so that it is accepted with the understanding that financial assets in the company have an effect on committing fraud, the opportunity for the nature of industry to affect the fraudulent financial statement with a significant level of 0.001 where smaller than the significant level in this study which is 0.01 so it is accepted with the understanding that warehouse inventory can be a trigger for someone to commit fraud, the rationalization of total accruals has an effect on fraudulent financial statements with a significant level of 0.003 which is smaller than the significant level in this study which is 0.01 so it is accepted with the understanding that the total accruals owned by the company have an impact because someone can commit fraud by falsifying total accruals, and the ability to use a dummy has no effect on fraudulent financial statements with a significant level of 0.295 which is greater than the significant level in this study which is 0.01 so that it is rejected with the understanding that the change of directors is not a factor in someone committing fraud.
\end{abstract}

Keywords: Financial Stability; Nature of Industry; Rationalization; Capability; Fraudulent Financial Statement

\section{INTRODUCTION}

\subsection{Research Background}

According to IAI (2014), every company is required to make financial reports that aim to provide information and data related to the company's finances, company performance, and cash flows regarding the use of resources that have been entrusted to them. That way, companies must make financial reports that are accurate and relevant for users of financial statements, but not all companies understand the importance of financial statements that are free from fraud. The financial report aims to make it easier for the company itself when it wants to re-evaluate the required accounts. In the financial statements, there are four types of financial reports, namely: income statement, capital statement, balance sheet, and cash flow statement. 
According to SAS No.99 in a study conducted by Koroy (2008) states that an auditor should have confidence that misstatements in financial statements can be found.

At this time, cheating was prevalent in various parts of the world which was very detrimental to everyone. Based on a survey conducted by ACFE (Association of Certified Fraud Examiners) in 2019 against Indonesia with a total of 239 respondents, it shows that most fraud occurred in Indonesia, namely corruption with a percentage of $64.4 \%$ or chosen by 154 respondents. The type of fraud that was committed was the misuse of state and company assets / assets of $28.9 \%$, which 69 respondents chose, and 16 other respondents chose fraud in the financial statements with a percentage of $6.7 \%$. The results of this survey are different from the results of a survey conducted by ACFE in 2018 where the biggest fraud occurred in the misuse of assets by $89 \%$, corruption by $38 \%$, and fraud in financial statements was $10 \%$. This result is due to the increase in the level of corruption in the years 2004-2018.

According to Thoyibatun (2009) fraud has become the center of attention, especially in the media where fraud is done deliberately manipulating company data and information for its own interests, such as gaining greater profits. The independent variable taken in this study is the fraud diamond. In conducting this research, fraud diamond has 4 important elements, namely: pressure, opportunity, rationalization, and capability. Pressure has three conditions in it, namely financial stability, external pressure, personal financial need, and financial targets. Meanwhile, there are two conditions, namely: nature of industry and effective monitoring. Companies often experience fraud in making financial statements, this makes researchers want to know whether companies experience fraud in financial statements by using fraud diamonds so that researchers raise the topic of the influence of fraud diamonds on fraudulent financial statements. In this study each element of the fraud diamond will be taken in one condition so that this study uses financial stability, effective monitoring, rationalization, and capability. Researchers selected companies in Asia-Pacific with a period from 2017-2019. This research is different from the previous research because this research took companies in Asia-Pacific. Therefore, the researcher wanted to find out how the fraud diamond had an effect on fraudulent financial statements in companies in Asia-Pacific. The thing that distinguishes this research from previous research is the company sample taken, the formula used as a proxy in the study, the number of samples taken, the period used in the study, the testing method applied.

\subsection{Theoretical Basis and Hypothesis Development 1.2.1 Agency Theory}

Agency theory explains the relationship between shareholders as the principal and management as the agent. Management is a party contracted by shareholders who work for the interests of shareholders so that those who have been elected by shareholders must be accountable for all the work they have done to shareholders. According to Jensen and Meckling (1976), agency theory is a contract involving one or more agents which aims to perform several services for them by delegating decision-making authority to agents. The purpose of this theory is to explain how the related parties can describe the contract which aims to minimize costs that will be incurred as a result of unbalanced information and uncertainty conditions. In agency theory, the principal expects the agent to be able to perform certain tasks in the interests of the principal, but on the other hand, the agent will act according to their own interests. If something happens in the company, such as financial difficulties or weak internal control, the principal may not know it because the agent does not provide this information.

\subsubsection{Financial Statements}

According to the Indonesian Institute of Accountants (2009: 1), financial statements generally consist of balance sheets, income statements, changes in equity reports, statements of 
financial position, notes and other reports, and explanatory material that is still an integral part of a financial report. Meanwhile, according to PSAK No.1 (2015: 1) says that the financial report is a structured presentation of the financial position and financial performance of an entity. Each company will produce financial reports that aim to make it easier for the company, provide guidance within the company for forecasting business growth, and provide guidelines in assessing funding and operational activities. The function of financial reports is to be used as review material, guidelines in making decisions, creating new strategies, and increasing company credibility. There are 4 tigers of financial reports, Profit and Loss Statements, Change in Capital Reports, Balance Sheet Statements, and Cash Flow Statements.

\subsubsection{Fraud}

Fraud (fraud) is an intentional act committed by one or more individuals in management or those responsible for governance, employees, and third parties that involve the use of deception to gain an unfair advantage or break the law (IAPI, 2013). According to Rozmita (2013), fraud is a deviation, error and irregularity in financial problems (irregularities). According to The Association of Certified Fraud Examiners (ACFE), which is a professional organization engaged in fraud examination. They classify fraud into three levels called the Fraud Tree, including: Deviation of assets, false or misstated statements, and corruption. COSO issues five aspects of control to prevent fraud, namely the control environment, risk assessment, control standards, information and communication, and monitoring.

\subsubsection{Fraud Triangle}

The fraud triangle is a theory that has been stated by Donald R. Cressey after he did more in-depth research in 1950. Cressey said that someone can commit fraud when the person has financial problems so that the person thinks that financial problems can be settled by their position in which the position is trusted by the company to hold the assets. The fraud triangle was first pointed out in SAS No. 99 which is standardized in the United States so that according to SAS No.99 the fraud triangle consists of pressure, opportunity, and rationalization. These three components encourage someone to commit cheating. Pressure related to management and other employees has pressure in committing fraud, opportunity is an opportunity that arises before there is fraud, and justification for action is a justification for fraud committed by the perpetrator.

\subsubsection{Fraud Diamond}

Fraud diamond is a new model for improving the fraud triangle theory proposed by Wolfe and Hermanson in 2004 by adding a capability element to enhance this model. They argue that a lot of fraud that is carried out by withdrawing large amounts of money will not occur if you do not have special abilities in the company. The fraud diamond theory has four important elements, including pressure which has four conditions, namely financial stability, external pressure, personal financial need, financial targets, opportunity which has two conditions, namely Nature of industry and effective monitoring, justification for actions (rationalization) and capability

\subsubsection{Fraudulent Financial Statement}

According to Karyono (2013: 17), fraudulent financial statements are the overstatement or understatement of the company's financial statements. By increasing the financial statements, you will benefit from the sale of shares and it is not difficult to get financing. Meanwhile, when the financial statements are published, it aims to avoid taxes so that they are not too high. International Standard Auditing states that there is fraud in financial 
statements that results in intentional misstatement, negligence in presenting amounts (Tuanakotta, 2014: 204). According to IAI (2001), there are two misstatements, they can be due to errors or fraud. Intentional misstatement in financial statements aims to gain personal gain.

\subsubsection{Fraud Score (F-Score)}

The F-score was first introduced by Dachow et al., In 2009, according to Sukrisnadi (2010), saying that the F-score is a form of measurement that can be claimed as a tool to detect material misstatements in financial reports. According to Dechow et al., (2009) in their research, he said that this model has an accuracy rate of $68-70 \%$ but this accuracy returns to the ongoing fraud case. The F-score has two components, namely accrual quality and financial performance which are defined as follows: accrual quality and financial performance. The purpose of developing the F-Score is to be able to calculate directly with the information in the financial statements and make it easier for readers to find out which financial statements are misstated and not misstated. The guidelines used to assess the F-Score in measuring the risk of material misstatement in the financial statements include:

- F-Score> 2.45 High Risk

- F-Score> 1.85 Substantial Risk

- F-Score $>1$ Above Normal Risk

- F-Score <1 Low / Normal Risk

\subsection{Framework}

This study uses a fraud diamond as a fraud detector in financial statements where the fraud diamond was initiated by Wolfe and Hermanson in 2004 which has four elements, namely pressure, opportunity, rationalization, and capability. The title of this research is THE EFFECT OF FRAUD DIAMOND ON FRAUDULENT FINANCIAL STATEMENT IN ASIA-PACIFIC COMPANIES. The following is a picture of the research model:

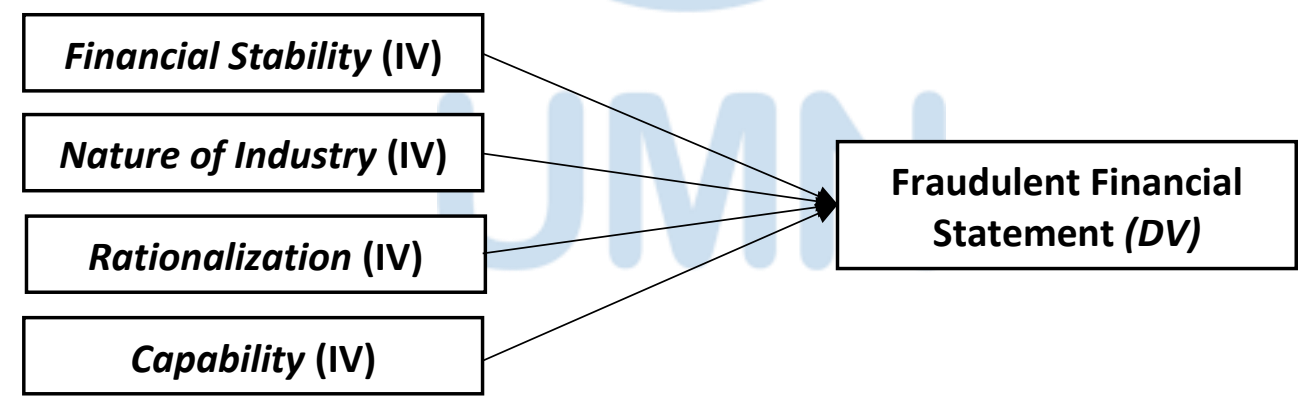

H1: Financial stability has an effect on the fraudulent financial statement

H2: Nature of industry affects fraudulent financial statements

H3: Rationalization affects the fraudulent financial statement

H4: Change of directors affects the fraudulent financial statement

\section{RESEARCH METHOD}

\subsection{Population, Sample, Data Source}

The population selected by the researcher were all manufacturing companies registered with the S\&P. In selecting the sample to be used, the researcher chose to use purposive sampling. According to Jogiyanto (2010), purposive sampling is taking samples from the population based on certain criteria. The method used by researchers to collect data is the quantitative method, by looking at the financial statements of companies in Asia-Pacific on the S\&P website (https://platform.marketintelligence.spglobal.com). 


\subsection{Research Empirical Model}

$\alpha:$ constant

$$
\text { FFS }=\alpha_{0}+\alpha_{1} \mathrm{FS}_{\mathrm{it}}+\alpha_{2} \mathrm{NOS}_{\mathrm{it}}+\alpha_{3} \mathrm{TA}_{\mathrm{it}}+\alpha_{4} \mathrm{CAP}_{\mathrm{it}}+e_{\mathrm{it}}
$$

FFS : Fraudulent Financial Statement

FS : Financial Stability

NOS : Nature of Industry

TA : Razionalization

CAP : Capability

e : eror

\subsection{Definition of Operational Variables}

- Fraudulent Financial Statement (FFS)

The formula for the fraudulent financial statement ratio:

$$
\text { F-Score }=\text { Accrual Quality }+ \text { Financial Performance }
$$

$$
\text { RSST accrual } \quad=\frac{\Delta W C+\Delta N C O+\Delta F I N}{\text { Average Total Assets }}
$$

- Financial Performance $=$ Change Receivable + Change in Inventory + Change in Cash Sales + Change in Earning

- Financial Stability (FS)

The ratio formula for financial stability uses the ratio of changes in assets as follows:

$$
\text { ACHANGE }=\frac{\text { Total Aset } t-\text { Total Aset }(t-1)}{\text { Total Aset }(t-1)}
$$

- Nature Of Industry (NOS)

Nature of Industry uses the following formula:

$$
\text { Inventory }=\frac{\text { Inventory } t}{\text { Sales } t}-\frac{\text { Inventory }(t-1)}{\text { Sales }(t-1)}
$$

\section{- Rationalization (TA)}

The formula for rationalization is:

$$
\text { Total Akrual }=\frac{\text { Net Income }- \text { Cash Flow From Operating Activity }}{\text { Total Aset }}
$$

- Capability: Change of Directors

Based on research conducted by Sihombing and Rahardjo (2014), they say that the change of directors is with dummy variables, where $1=$ there is a change of directors for 3 years and $0=$ no change of directors for 3 years.

\subsection{Data analysis method}

The method used in this research is to use the application of multiple regression models with the Stata software program. Researchers use stata because they provide features of 
analysis and data processing that are more complete and efficient than other programs. The analysis technique used is descriptive statistics, correlation test, classic assumption test in the form of normality test, multicollinearity test, heteroscedasticity stest, determination coefficient test, simultaneous significance test (F statistical test), and t statistical test.

\section{RESULTS AND DISCUSSION}

\subsection{Description of Research Objects}

The object of research taken is in the form of companies operating in Asia-Pacific and registered with S\&P. This study used a purposive sampling method based on predetermined criteria for data collection. From the results of data collection in the S\&P, there were a sample of 228 that met the predetermined criteria. The number of samples taken has met the criteria for the central limit theory which states that a large number of samples can be said to be normally distributed if the sample is 30 unless there is a limited sample. There are several characteristics used in this study so that the research results are more accurate, including companies operating in Asia-Pacific that are registered with S\&P and have been operating for at least 5 years and the financial statements used for 2017-2019 are in English/Indonesian.

\subsection{Descriptive statistical test}

Tabel 1. Descriptive Statistics

\begin{tabular}{|l|r|r|r|r|r|}
\hline Main Variabel & \multicolumn{1}{l|}{ Mean } & \multicolumn{1}{l|l}{ Median } & \multicolumn{1}{l}{ Minimum } & \multicolumn{1}{l}{ Maximum } & \multicolumn{1}{l}{ Std. Deviation } \\
\hline ffs & .0816134 & .1230825 & -2.911279 & 1.103613 & .4291384 \\
\hline fs & .0909252 & .0753936 & -.3230963 & 2.029183 & .2038128 \\
\hline nos & .0259506 & .0016165 & -1.395996 & 1.946091 & .2340939 \\
\hline ta & -.0146818 & -.0146337 & -.6581951 & .2803544 & .099817 \\
\hline cap & .5789474 & 1 & 0 & 1 & .4948143 \\
\hline
\end{tabular}

The table above is an overview of the five variables used in conducting this research using 178 financial reports for the 2017-2019 period. It can be interpreted as follows: Financial Statement Fraud (ffs): the mean value of the Financial Statement Fraud (ffs) of 228 data for the 2017-2019 period is 0.0816134 which has a standard deviation of 0.4291384 . The maximum value of this variable is 1.103613 and the minimum value, the minimum value is -2.911279 . Financial Stability (fs): the mean value of Financial Stability (fs) is 0.0909252 which has a standard deviation obtained is 0.2038128 . The maximum value of this variable is 2.029183 and the minimum value is -0.3230963 . Nature of Industry (nos): the mean value obtained from Nature of Industry (nos) is 0.0259506 which has a standard deviation obtained in this variable is 0.2340939 . The maximum value obtained is 1.946091 and the minimum value is 1.395996.Razionalization (ta): the mean value of rationalization (ta) is -0.0146818 which has a standard deviation of 0.099817 . The maximum value obtained is 0.2803544 and the minimum value is -0.6581951 Capability (cap): the mean value obtained from this Capability (cap) variable using the dummy is 0.5789474 which has a standard deviation obtained is 0.4948143 , meaning that there is $\pm 49.48143 \%$ there is a deviation. The maximum value obtained is 1 and the minimum value is 0 .

\subsection{Correlation Test}


Tabel 2. Correlation Test

\begin{tabular}{|l|l|l|l|l|l|}
\hline & ffs & fs & nos & ta & cap \\
\hline ffs & 1.0000 & & & & \\
\hline fs & $0.4457^{*}$ & 1.0000 & & & \\
\hline nos & $-0.5070^{*}$ & -0.0832 & 1.0000 & & \\
\hline ta & $0.4851^{*}$ & $0.2114^{*}$ & -0.0217 & 1.0000 & \\
\hline cap & -0.0460 & 0.0330 & 0.0591 & -0.0376 & 1.0000 \\
\hline
\end{tabular}

In the table above, you can see that there is an asterisk (*) on the correlation test between financial stability (fs) and fraudulent financial statement (ffs) resulting in a coefficient of 0.4457. Meanwhile, nature of industry (nos) with fraudulent financial statement (ffs) produces a coefficient of -0.5070 . The result of the correlation test between rationalization (ta) and fraudulent financial statement (ffs) produces a coefficient of 0.4851 . The result of the correlation test between rationalization (ta) and financial stability (fs) produces a coefficient of 0.2114 . In the results of this correlation test, there is no indication of multicollinearity because the coefficient on each variable is not greater than 0.8 and insignificant because it is $<0.1$, so it is said not to experience multicollinearity.

\subsection{Normality test}

Tabel 3. Normality Test

\begin{tabular}{|c|c|r|r|r|r|}
\hline \multicolumn{7}{|c|}{ Skewness/Kurtosis tests for Normality } \\
\hline \multicolumn{7}{|c|}{} \\
\hline Variabel & Obs & Pr(Skewness) & Pr(Kurtosis) & adj. Chi2(2) & Prob>Chi2 \\
\hline ffs & 228 & 0.0000 & 0.0000 & &. \\
\hline
\end{tabular}

Based on the normality test carried out, it can be seen that the data used has not been normally distributed with Prob> $\mathrm{z}$ of 0.00000 so that this data needs to be treated so that it can be normally distributed using the skewness-kurtosis test.

Table 4. Treatment Results

\begin{tabular}{|c|c|r|r|r|r|}
\hline \multicolumn{7}{|c|}{ Skewness/Kurtosis tests for Normality } \\
\hline Variabel & Obs & $\operatorname{Pr}($ Skewness) & Pr(Kurtosis) & adj. Chi2(2) & Prob>Chi2 \\
\hline bc_ffs & 160 & 1.0000 & 0.7185 & 0.13 & 0.9371 \\
\hline
\end{tabular}

From the results of treatment it can be said that the data used in the study are still not normal, but with data of more than 200 observations the researcher can ignore the results of the 
treatment and the data is considered normal. So the data that have not been distributed normally after the skewness-kurtosis test treatment is normal.

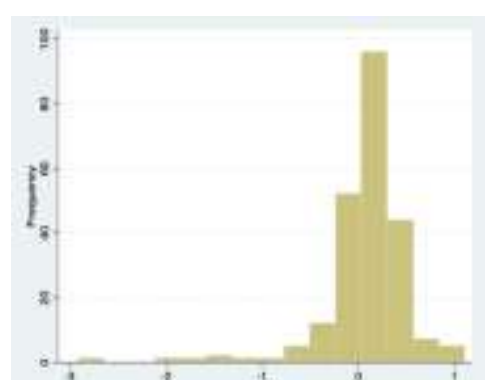

Figure 1. Normality Test Results: Histogram Graph

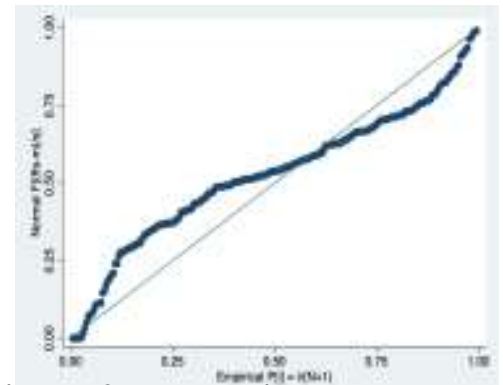

Figure 2. Normality Test Results: Normal Probabilitv Plot Granh

Based on Figure 4.1. Related to the results of the normality test in the form of a histogram graphic, it gives a pattern that is close to normal distribution, but if you pay attention to the figure, there are some data that are far on the left side of the distribution pattern, while in Figure 4.2. Related to the results of the normality test in the form of a normal probability plot graph, it shows the distribution points on the diagonal line and the distribution follows the direction of the line. So it can be concluded that the regression model for this study meets the normality assumption test.

\subsection{Multicollinearity Test}

Tabel 5. Multicollinearity Test

\begin{tabular}{|c|c|c|}
\hline Variabel & VIF & 1/VIF \\
\hline fs & 1.06 & 0.947061 \\
\hline nos & 1.05 & 0.953326 \\
\hline ta & 1.01 & 0.989257 \\
\hline cap & 1.01 & 0.993005 \\
\hline Mean VIF & 1.03 & \\
\hline
\end{tabular}

The multicollinearity test serves to find out whether there is a correlation between the independent variables with one another by looking at the Tolerance or Variance Inflation Factor (VIF) value. If the Tolerance value $>0.1$ or VIF $<10$ then there is no multicollinearity problem. Based on the test results in Table 5, it can be seen that there is no high multicollinearity problem between the independent variables because the value generated in this test is a mean VIF value of 1.03 where the anchor is less than 10 . 


\subsection{Heteroscedasticity Test}

Tabel 6. Heteroscedasticity Test

\begin{tabular}{|l|l|}
\hline \multicolumn{2}{|c|}{ Estat Hettest } \\
\hline Chi2(1) & 0.39 \\
\hline Prob>chi2 & 0.5335 \\
\hline
\end{tabular}

The heteroscedasticity test has the aim of finding out whether the residual variance from one observation with other observations is fixed or not. Based on the results of this test, it can be seen that there is no problem in heteroscedasticity because the value of chi2 (1) is 0.39 smaller than the value Prob> chi 2 with a value of 0.5335 and the probability value is greater than 0 .

\subsection{Hypothesis testing}

Tabel 7. Hypothesis Testing

\begin{tabular}{|c|c|c|c|}
\hline \multirow[t]{2}{*}{ Variabel Independen } & \multicolumn{3}{|c|}{ Variabel Dependen : FFS } \\
\hline & Koefisien & $\mathbf{t}$ & Sig. \\
\hline Constant & -1.348837 & -22.52 & 0.000 \\
\hline FS & .9674339 & 5.56 & 0.000 \\
\hline NOS & -.7859848 & -3.29 & 0.001 \\
\hline TA & 1.52573 & 2.98 & 0.003 \\
\hline CAP & -.0771113 & -1.05 & 0.295 \\
\hline R-squared & 0.2393 & & \\
\hline Adj R-squared & 0.2197 & & \\
\hline Sig. & 0.0000 & & \\
\hline $\mathbf{n}$ & 160 & & \\
\hline
\end{tabular}

\subsubsection{Determination Coefficient Test}

The coefficient of determination serves to show the magnitude of the model's ability in research to explain the independent variables. The coefficient of determination test has a weakness in the use of R-Square, namely the emergence of bias in the number of independent variables and how to overcome the problem of bias that arises from this R-Square, so this test will focus on the Adjusted R-Square as a complement.Based on table 7, the Adjusted R-Square value is 0.2197 which means that the total of fraudulent financial statement variables can be explained by the variables of financial stability, nature of industry, rationalization and capability of $21.97 \%$ and the remaining $78.03 \%$ is explained by other external variables. this research model. 


\subsubsection{Simultaneous Significance Test (Test Statistic F)}

The F statistic test aims to find out whether the independent variable in the study affects the dependent variable.Based on table 7, the calculated F value is 12.19 with Prob> F of 0.0000 which means that the variables financial stability, nature of industry, rationalization, and capability simultaneously affect the fraudulent financial statement variable. With a probability value of $0.0000<0.05, \mathrm{H} 0$ is rejected so that the independent variable can simultaneously influence the dependent variable.

\subsubsection{Multiple Linear Regression Analysis}

Based on Table 7, the regression model used is as follows:

\section{FFS $=\alpha 0+\alpha 1$ FSit $+\alpha 2$ NOSit $+\alpha 3$ TAit $+\alpha 4$ CAPit + eit $=-1.348837+0.9674339$ FSit -0.7859848 NOSit + 1.52573 TAit -0.0771113 CAPit + eit}

The definition of the regression model above is:

1. A constant value of 0.0749752 with a negative direction means that if FS, NOS, TA, and Cap are not valued or zero, then the FFS will be worth -1.348837 .

2. The FS regression coefficient value is 0.9674339 with a positive direction, so if the other

independent variables still mean that each FS increment is 1 unit, then there is a potential increase of 0.9674339 units in the fraudulent financial statement.

3. The NOS regression coefficient value is 0.7859848 with a negative direction. If the other

independent variables still mean that each increase in NOS is 1 unit, there is a potential decrease of 0.7859848 units in the fraudulent financial statement.

4. The TA regression coefficient value is 1.52573 with a positive direction, so if other independent variables still mean that each TA increase is 1 unit, there is a potential for an increase of 1.52573 units in the fraudulent financial statement.

5. The CAP regression coefficient value is 0.0771113 with a negative direction, so if the other

6. independent variables still mean that each increase in CAP is 1 unit, then there is a potential decrease of 0.0771113 units in the fraudulent financial statement.

\subsubsection{Statistical test $t$}

The $\mathrm{t}$ statistic test aims to show how much influence the independent variable has in explaining the dependent variable. Based on the coefficient and t-count in table 7, it is found that prob> $F$ is 0.000 with a significance of 0.01 or 1 percent with a t-test of 2.576 . If seen in the table, the FFs variable gets the number 0.000 , Nos gets the number 0.001 , ta gets the number 0.003 , and the cap gets the number 0.295 so that only the capability variable is rejected because the value is greater than 0.05 and the rest is accepted with the understanding that there is a relationship between the independent variable and the variable dependent.

\subsection{The Effect of Financial Stability on the Fraudulent Financial Statement}

Based on the results of the regression analysis on the financial stability variable using changes in total assets as a proxy in this study, it has a coefficient of 0.9674339 and a significant level of $0.000<0.01$. The test results mean that financial stability has an effect on fraudulent financial statements so that the higher the change in total assets of a company, the value of asset growth of the company also increases, and the lower the potential for fraudulent financial statements. So based on the results in table 7, hypothesis 1 is accepted. 


\section{The Influence of Nature of Industry on the Fraudulent Financial Statement}

Based on the results of the regression analysis on the nature of industry variable using total inventory as a proxy in this study, it has a coefficient of -0.785984 and a significant level of $0.001<0.01$. The existence of risks that arise within the company that involves considerable estimates and considerations is one of the factors of the opportunity so that the company's financial statements always make estimation accounts such as bad debts and inventory accounts. Intentional errors become an opportunity for management to commit fraud in the estimation of inventory balances and according to Skousen et al., (2009) states that a management will always focus on the estimation of bad debts accounts and estimates of obsolete inventory accounts if he has the intention to take action. the fraud. So the conclusion from the results of the hypothesis test in Table 7, hypothesis 2 is accepted where the company can falsify the inventory account where the estimated inventory account is difficult to hide without being suspected by other parties.

\subsection{The Effect of Rationalization on the Fraudulent Financial Statement}

Accrual is a way in which the company makes receipts and expenses that will be recognized or will be recorded when the transaction has occurred, not when cash is received or paid. The concept of discretionary accruals means that management can falsify income by recording when the transaction occurs where the company's cash has not been issued or received. So that with the high discretionary accruals in the company, it is possible that the fraud committed in the company will be higher and vice versa if the discretionary accruals in the company decrease, the fraud committed within the company will also decrease. Based on the results of the regression analysis on the rationalization variable using total accruals to total assets as a proxy in this study, it has a coefficient of 1.52573 and a significant level of 0.003 $<0.01$. So based on the results of hypothesis testing in Table 7, hypothesis 3 is accepted.

\subsection{The Effect of Capability on the Fraudulent Financial Statement}

Based on the results of the regression analysis on the capability variable using the change of the board The change of the board of directors is an indication that the ability of the board of directors is not good in carrying out their duties so that the change of directors is carried out in order to improve the performance that has been produced previously. When the company does not change the board of directors, it can be said that the board of directors is good enough in managing the company so that the company does not change the board of directors. Based on the results of the regression analysis on the capability variable using the change of the board of directors as a proxy in this study, it has a coefficient of -0.0771113 and a significant level of $0.295<0.01$ where the significance of this variable is greater than 0.01 or 1 percent.

\section{CONCLUSIONS AND SUGGESTIONS 4.1. Conclusion}

Based on the results of testing and discussion conducted in detecting fraudulent financial statements using the pressure factor approach which is proxied by financial stability, the opportunity factor proxied by the nature of the industry, the rationalization factor, and the capability factor of companies in Asia-Pacific that have registered with the S\&P with the period 2017-2019, the following conclusions can be drawn:

1. Financial stability has an effect on fraudulent financial statements so that $\mathrm{H} 1$ is Accepted where every increase in the ratio of changes in total assets will increase the possibility of fraud so that the higher ratio of changes in total assets increases the probability of the company to be able to commit fraud in a stable company's money. 
2. Nature of industry has an effect on fraudulent financial statements so that $\mathrm{H} 2$ is Accepted where companies that have large amounts of inventory will provide opportunities to commit fraud and besides that the inventory account is a very significant account in the balance sheet so it is often used as an intermediary to manipulate reports. finance.

3. Rationalization has an effect on fraudulent financial statements so that $\mathrm{H} 3$ is accepted where high discretionary accruals in the company are most likely management can falsify high data also by recording recognized receipts and expenditures transactions.

4. Capability has no effect on fraudulent financial statements, so $\mathrm{H} 4$ is rejected where the change of directors carried out in the company went well because the new directors with their ability to protect the company from fraud in the financial statements so that the change of directors minimized the occurrence of fraud in the financial statements.

\subsection{Suggestion}

Based on the conclusions above, it is hoped that this can serve as a guide for further research, considering the suggestions given, including:

1. Further research is expected to add more samples and add reporting periods and add other variables to detect fraudulent financial statements.

2. Further research is expected to look for reference sources from abroad as well.

3. Further research is expected to increase references and develop this research using the F-Score as a measuring tool.

4. Further research is expected to find out and find new proxies for the capability variable due to the limited existing proxies.

\subsection{Research Limitations}

In conducting this research, the researcher has several limitations, including:

1. The sample taken is only in the Asia-Pacific region that has been registered with S\&P.

2. The sample taken has been operating for at least 5 years with financial reports using English/Indonesian in 2017-2019.

3. The use of the F-Score as a measuring tool for detecting fraudulent financial statements is still rarely used, so further research is still needed.

4. Limited proxies used for opportunity and capability variables (there is only one way).

5. The capability variable is the only independent variable that uses a dummy variable that is proxied by the change of directors.

\section{REFERENCES}

ACFE. (2019). Survei Fraud Indonesia.

Annisya, M., Lindrianasari, dan Asmaranti, Y. (2016). Pendeteksian Kecurangan Laporan Keuangan Menggunakan Fraud Diamond. Jurnal Bisnis dan Ekonomi (JBE), Maret 2016, Hal. 72 - 89 Vol. 23, No. 1. Lampung.

artikelpendidikan.com. (2020). Teori Agensi Menurut Para Ahli Dalam Praktek Akuntansi.

Aulia, H. (2018). Analisis Fraud Diamond Dalam Mendeteksi Potensi Kecurangan Laporan Keuangan (Studi Pada Perusahaan Manufaktur Yang Terdaftar Di BEI Tahun 20142016). Yogyakarta.

Farizi, Z. A., Tarmizi, T., dan Andriana, S. (2020). Fraud Diamond Terhadap Financial Statement Fraud. Jurnal Akuntansi Dan Bisnis Vol 5, No 1, Juni 2020, Hal 71-82. Pontianak. 
Fikri, M. K. (2017). Mengkaji Pendeteksian Financial Statement Fraud Melalui Pendekatan Faktor Pressure, Opportunity, Rationalization, Dan Capability Dalam Perspektif Analisis Fraud Diamond. Semarang.

Nurfalah, D. R. (2016). Perkembangan Teori Fraud.

Oktarigusta, L. (2017). Analisis Fraud Diamond Untuk Mendeteksi Terjadinya Financial Statement Fraud Di Perusahaan (Studi Empiris Pada Perusahaan Manufaktur Yang Terdaftar Di BEI Tahun 2012-2015). Jurnal Ekonomi Manajemen Sumber Daya Vol. 19, No. 2, Desember 2017.

Putri, R. A. (2015). Analisis Fraud Diamond Dalam Mendeteksi Fraudulent Financial Statement (Studi Empiris pada Perusahaan Perbankan yang Terdaftar di Bursa Efek Indonesia Tahun 2011-2014). Jakarta.

Rasiman dan Rachbini, W. (2018). Fraud Diamond dan Deteksi Kecurangan Laporan Keuangan Perusahaan Food and Beverage di Bursa Efek Indonesia. Jurnal Riset Akuntansi dan Perpajakan JRAP Vol. 5, No. 2, Desember 2018, hal 188-200. Jakarta Selatan.

Sari, S. T. (2016). Pengaruh Financial Stability, External Pressure, Financial Targets, Ineffective Monitoring, Rationalization Pada Financial Statement Fraud Dengan Perspektif Fraud Triangle (Studi Empiris Pada Perusahaan Perbankan Periode 20122014 Yang Terdaftar Di Bursa Efek Indonesia). JOM Fekon Vol. 3 No. 1 (Februari) 2016. Pekanbaru.

Sihombing, K.S., dan Rahardjo, S.N. (2014). Analisis Fraud Diamond Dalam Mendeteksi Financial Statement Fraud: Studi Empiris Pada Perusahaan Manufaktur Yang Terdaftar Di Bursa Efek Indonesia (BEI) Tahun 2010-2012. Diponegoro Jurnal Of Accounting, 3 (02), 1-12.

Wicaksana, E. A., \& Suryandari, D. (2019). Pendeteksian Kecurangan Laporan Keuangan Pada Perusahaan Pertambangan Di Bursa Efek Indonesia. Jurnal RAK (Riset Akuntansi Keuangan), Vol. 4 No. 1. Semarang. 